\title{
Bank Sampah Digital Kota Serang Sebagai Gerakan Lingkungan Berbasis Digital Movement
}

\section{Tiara Ayu Rahmadanty ${ }^{1}$}

Ilmu pemerintahan, Universitas Sultan Ageng Tirtayasa 6670180025@untirta.ac.id

\section{Khafifah Nurulita Suheri ${ }^{2}$}

Ilmu pemerintahan, Universitas Sultan Ageng Tirtayasa 6670180026@untirta.ac.id

\section{Nida Nurhopia ${ }^{3}$}

Ilmu pemerintahan, Universitas Sultan Ageng Tirtayasa 6670180070@untirta.ac.id

\section{Lina Mulyanih ${ }^{4}$}

Ilmu pemerintahan, Universitas Sultan Ageng Tirtayasa 6670180109@untirta.ac.id
E-ISSN 2721-0642

Article Info

Recieved:

May 132021

Revised:

July 222021

Accepted:

July 292021

Doi Number

https://doi.org/10.37950/ijd.v3i2.104

\section{Abstract}

This study describes the Environmental Movement which is carried out on a digital basis. The merger between the digital-based environmental movement which is a movement for environmental awareness carried out through digital media that has an impact on real action in social life and becomes a new innovation in carrying out social movements. The basic thing about the presence of this social movement is that the environmental imbalance that is formed due to the accumulation of garbage has a negative impact, especially in the city of Serang, making several people form this movement. This study uses a descriptive qualitative method approach in it, by describing the presence of the Digital Waste Bank movement as a digital-based environmental movement. What's more interesting is the pandemic situation that actually made this movement present which was then implemented in the form of a digital movement with real results in the city of Serang.

Keywords: Environmental Movement, Digital Waste Bank, Digital Movement

\section{Abstrak}

Penelitian ini menjelaskan tentang Gerakan Lingkungan yang dilakukan dengan basis digital. Penggabungan antara Gerakan lingkungan berbasis digital yang merupakan Gerakan kepedulian terhadap lingkungan yang dilakukan melalui media 
digital yang berdampak pada aksi nyata dikehidupan bermasyarakat dan menjadi inovasi baru dalam melakukan Gerakan sosial. Hal mendasar hadirnya Gerakan sosial ini adalah ketidakseimbangan lingkungan yang terbentuk akibat penumpukan sampah memberikan dampak negatif khususnya di Kota Serang menjadikan beberapa masyarakat membentuk Gerakan ini. Penelitian ini menggunakan pendekatan metode kualitatif deskriptif didalamnya, dengan mendeskripsikan terkait kehadiran gerakan Bank Sampah Digital sebagai gerakan lingkungan berbasis digital. Terlebih yang menjadi menarik adalah keadaan pandemi yang justru membuat Gerakan ini hadir yang kemudian diimplementasikan dalam bentuk Gerakan digital dengan hasil Gerakan nyata di Kota Serang.

Kata kunci: Gerakan Lingkungan, Bank Sampah Digital, Gerakan Digital

\section{Pendahuluan}

Semakin berkembangnya zaman yang diikuti dengan jumlah pertumbuhan penduduk yang semakin tinggi, memberikan banyak dampak salah satunya terhadap keberlangsungan lingkungan disekitarnya. Salah satu dampak yang terlihat adalah kehadiran sampah sebagai output dari kegiatan pemenuhan kebutuhan manusia. Sampah menjadi salah satu hal yang tidak terhindarkan lagi, hal ini terjadi karena bertambahnya jumlah penduduk diikuti dengan pola konsumerisme masyarakat juga mampu menyumbang jenis-jenis sampah lainnya. Sampah yang dihasilkan ini sering kali hanya memberikan dampak negatif karena setiap individu tidak mengolah terlebih dahulu mana sampah yang sekiranya masuk dalam jenis sampah kering, basah, dan lain-lain. Masyarakat melakukan pengelolaan sampah masih belum menggunakan cara penelolaan yang tepat, berwawasan lingkungan sehingga salah satunya mampu memicu dampak negatif bagi kesehatan masyarakat dan lingkungan. Dengan begitu sampah merupakan masalah nasional yang dimana pengelolaan sampah perlu di lakukannya dengan cara komprehensif sehingga dapat memberikan manfaat bagi masyarakat, baik memberi manfaat kesehatan, hingga lingkungan serta harapannya mampu merubah perilaku masyarakat terkait cara pengelolaan sampah.

Maka diperlukannya gerakan yang mampu mengakomodasi setiap peran masyarakat untuk mampu mengolah sampah sebelum menuju Tempat Pembuangan Sampah Sementara (TPS). Gerakan yang bukan hanya berorinetasi pada pembuangan sampah tetapi juga pada pemilahan, pengelolaan hingga pemrosesan pada sampah itu sendiri sebelum menuju TPS.

Dalam pengolaan sampah terdapat beberapa tahapan yang disebut sebagai 3R (Reduce, Reuse, dan Recycle) yang diawali dengan gerakan untuk mengurangi sampah berarti bahwa adanya usaha berupa menghindari penggunaan barang yang akan berujung pada sampah yang sulit untuk diolah kembali seperti plasik. Kemudian penggunaan kembali sampah yang sekiranya mampu dan masih layak digunakan kembali untuk hal atau kegiatan lainnya. Hingga pada proses pendaur ulangan yang mampu mengurangi kuantitas sampah itu sendiri. Terakhir setelah itu harapannya setelah masyarkat mampu mengelola sampah, hal ini mampu menjadi manfaat dan juga memiliki nilai ekonomi. Atas dasar kepedulian lingkungan tersebut maka hadir suatu gerakan sosial yang disebut Environmental Movement dimana terdapat gerakan sosial yang merujuk pada materi tentang perjuangan lingkungan. Perjuangan yang 
dilakukan atas dasar keseimbangan ini dilakukan agar terciptanya keserasian lingkungan yang mampu saling memberi manfaat baik manusia atau kebersihan lingkungan itu sendiri.

Kemudian pada tahun 2019 meyebarnya virus Coronavirus disease 2019 (Covid19) atau yang dimana disebut sebagai pandemi ini terjadi dan dialami oleh hampir seluruh bagian dunia tak terkecuali Indonesia (Wahyuningsih, 2020). Dimana Keadaan mengharuskan setiap manusia melakukan kegiatan dengan menerapkan protokol Kesehatan salah satunya berjaga jarak, maka setiap kegiatan kini dilakukan dengan cara berusaha menaati protokol Kesehatan yaitu dengan kegiatan Dalam Jaringan (Daring). Tak terkecuali Gerakan sosial atau Sosial Movement yang banyak digencarkan melalui Internet. Hal ini dilakukan agar setiap asprirasi dari perjuangan Gerakan sosial tetap mampu tercipta walaupun dalam kedaan pandemi sekalipun.

Atas latar belakang tersebut maka terciptanya gerakan Bank Sampah digital yang berdiri sejak 2020 di Kota serang. Bank sampah merupakan suatu kegiatan yang bersifat social enterprise yang bertujuan untuk mengajarkan masyarakat cara mengelola sampah dan membuat kesadaran masyarakat tentang pentingnya mengelola sampah dengan baik dan dapat mengurangi sampah yang ada. Munculnya Bank sampah Digital merupakaan prakarsa lingkungan terkait perubahan terhadap permasalahan sampah mulai dari sampah rumah tangga hingga sampah produksi yang kemudian coba dikelola dengan bentuk kerjasama antara pemilik sampah dengan Bank Sampah Digital. Dengan begitu adanya bank sampah digital ini juga dapat mengurangi sampah dan menjadikan perekonomian berkembang bagi masyarakat.

Adanya bank sampah itu berasal dari insiatif masyarakat yang berpartisipasi aktif mengenai permasalahan sampah selama ini. Gerakan yang dilakukan melalui beberapa Platform Digital ini benar-benar dimanfaatkan sebagai wadah melakukan Gerakan sosial oleh Bank Sampah Digital. Gerakan yang tercipta atas keresahan yang terjadi pada lingkungan sekitar yang semakin lama juga mampu memiliki dampak bagi kesehatan manusia. Gerakan Bank Sampah Digital atau yang disingkat BSD ini merupakan Gerakan sosial yang tercipta karena permasalahan yang terjadi pada lingkungan sekitar di Kota Serang, khususnya permasalahan terkait pengelolaan sampah di Kota Serang.

\section{Kerangka Teori}

Beberapa tahun terakhir ini masyarakat mulai memanfaatkan media digital untuk menyampaikan aspirasi mereka, dimana gerakan yang muncul dari media sosial akan terbentuk sebagai sebuah gerakan dan massa yang benar-benar ada di dunia nyata. Media sosial benar-benar telah berhasil mempengaruhi kehidupan di dalam menyampaikan sebuah aspirasi atau pun keluh kesah terhadap objek Gerakan sosial. Adanya konsep dari aktivisme digital muncul saat teknologi dimanfaatkan untuk mendukung berbagai aktivitas dari kegiatan masyarakat sipil, terutama dalam konsep negara demokrasi. Dimana di dalam praktiknya teknologi tidak hanya dilihat sebagai sebuah sarana untuk berbicara luas dan cepat. Gerakan yang dilakuan melalui internet atau aktivisme digital merupakan wadah alternatif dalam menyampaikan aspirasi yang minim resiko tetapi mampu memberikan dampak maksimal menurut Laer \& Aelst (2010) dalam (Sanjaya, 2017). Kemudian gerakan digital ini banyak berkembang salah satunya digunakan dalam gerakan digital berbasis lingkungan.

Gerakan lingkungan kini berkembang, karena kepentingan akan keadaan lingkungan ini benar-benar dirasakan dampaknya oleh manusia. Maka hadirlah 
diskursus sosial tentang perjuangan terhadap lingkungan dimana menurut (Castro, 2004) keseimbangan lingkungan dianggap sebagai salah satu faktor adanya symbiosis mutualisme antara manusia dan lingkungan. Maka bila terjadi permasalahan terhadap lingkungan akan pula berpengaru terhadap manusianya.

Gerakan lingungan ini hadir atas iniasi oleh individu atau kelompok yang bertujuan untuk mengembalikan keseimbangan lingkungan, menurut (Aditjondro, 2003) Gerakan lingkungan ini didasari atas tiga konsep gerakan Public Environmentalist, merupakan suatu gerakan sosial berbasis lingkungan yang dilakukan oleh publik atau khalayak umum yang ditujukan untuk memperbaiki kondisi lingkungan yang dianggap sudah mengalami perubahan melalui tindakan atau aksi nyata yang dilakukan. Voluntary environmentalist atau Organized Environmentalist, merupakan suatu gerakan sosial berbasis lingkungan yang dilakukan oleh komunitas atau kelompok yang terorganisir yang didirikan dengan maksud untuk mengembalikan keseimbangan lingkungan yang dimana pada skala luas bisa menembus lintas negara. Dan Institusional Environmentalist Movement Organization, merupakan suatu gerakan sosial berbasis lingkungan baik kelompok atau individu yang mengklaim dirinya memiliki kewenangan atas lingkungan yang bergerak melalui jalur legal formal.

Seabagaimana topik pembahasan pada tulisan ini yaitu Bank Sampah Digital Kota Serang Sebagai Gerakan Lingkungan Berbasis Digital Movement, maka kajian teori yang sesuai dengan penelitian ini merujuk pada teori milik Christenson dan Robinson (1989) dalam (Suraji, 2012) terkait Community Development merupakan suatu proses dalam rangka memprakarsai suatu hal dengan tujuan melaksanakan tindakan atau gerakan untuk mengubah situasi baik situasi sosial, ekonomi, kultural hingga lingkungan yang dilakukan oleh kelompok atau komunitas yang sejalan dengan tujuan yang sama tanpa adanya intervensi.

\section{Metodologi Penelitian}

Metodologi penelitian yang digunakan adalah metode penelitian kualitatif menurut (Creswell, 2016) penelitian kulitatif yaitu adalah observasi yang mendapatkan penemuan-penemuan yang tidak dapat diperoleh dengan memakai metode-metode statistic ataupun cara-cara lain dari pengukuran melainkan pengumpulan data menggunakan sumber data dengan mengamati perilaku dan aktivitas individu di lokasi penelitian.

Pada penelitian ini dilakukan dengan metode multiple source of data atau beragam sumber data; antara lain wawancara ke Bank Sampah Digital Serang, observasi dengan melakukan pengamatan terhadap perilaku orang-orang yang dimana menjadi objek penelitian kami yaitu Bank Sampah Digital serta yang menjadi nasabah dari dari Bank Sampah digital, dokumentasi, dan juga penggunaan studi literatur yang berasal dari tulisan ilmiah serta sumber relevan. Pendekatan tersebut kami gunakan karena dirasa tepat dengan penelitian kami yang lebih mendeskripsikan bagaimana mereka memandang sebuah peritiswa social yang terjadi di tempat mereka tinggal.

\section{Hasil dan Diskusi \\ Bank Sampah Digital Kota Serang}

Dari data Dinas Lingkungan Hidup Kota Serang tahun 2019 Kota Serang menghasilkan 360 ton sampah perharinya, namun hanya 70-80 ton sampah saja yang mampu diangkut ke TPA (Tempat pembuangan akhir) Cilowong. Hal tersebut menimbulkan banyak sekali tumpukan sampah di jalan, sungai, dan lain-lain. Sampah 
yang sudah terangkut pun masih dalam kondisi tercampur yaitu organic dan anorganik. Dan karena itu bank sampah digital berdiri. Bank sampah digital sendiri berdiri di Kota Serang pada tahun 2020.

Bank sampah merupakan suatu kegiatan yang bersifat social enterprise yang bertujuan untuk mengajarkan masyarakat cara mengelola sampah dan membuat kesadaran masyarakat tentang pentingnya mengelola sampah dengan baik dan dapat mengurangi sampah yang ada. Bank sampah digital adalah Lembaga pengelola sampah kering yang berbasis masyarakat dengan platfom digital. Lalu system dari bank sampah adalah mendorong partisipasi aktif dari masyarakat untuk memilah serta menabung sampah bernilai ekonomis. Lalu dengan adanya system bank sampah diharapkan masyarakat akan lebih berdaya, lingkungan hidup semakin lestari serta keuntungan ekonomi akan di dapatkan masyarakat secara langsung.

Perbedaan bank sampah konvesional dan bank sampah digital adalah ekonomi inklusif yang artinya semua orang bisa terlibat, masyarakat lebih diberdayakan dan mendapatkan keuntungan, informasi yang disampaikan transparan, akuntabel, tersebar serta update, membangun jejaring bank sampah, bank sampah sebagai mitra langsung dari industry, dan promo lebih menarik dan update. Serta bank sampah konvesional ekonomi linera, harga monopoli, harga berubah-ubah tidak transparan, informasi tertutup, bank sampah sebagai kolektor, rewards yang diberikan kurang menarik.

Gerakan bank sampah digital Serang sendiri sudah mempunyai 97 titik sebaran yang berada di Kabupaten Serang, Kota Serang serta Cilegon. Dan sudah mempunyai lebih dari 1864 nasabah dari 97 titik sebaran tersebut. Sampah-sampah tersebut tidak hanya berakhir di tempat pembuangan sampah akan tetapi diolah Kembali manjadi produk yang bernilai ekonomis sehingga perekonomian warga pun semakin berkembang. Nasabah pun mendapatkan fasilitas yaitu kantung memilah, buku tabungan, serta sticker rumah.

\section{Pengelolaan Sampah Mengacu Kebijakan Pemerintah}

Regulasi pembentukan bank sampah tertuang di dalam Peraturan Menteri Lingkungan Hidup Republik Indonesia yaitu Nomor 13 Tahun 2012, dan tertulis di dalam pasal 1 Nomor 2 dari peraturan tersebut bahwa bank sampah adalah tempat pemilahan dan pengumpulan sampah ("Peraturan Menteri Negara Lingkungan Hidup Republik Indonesia Nomor 13 Tahun 2012 Tentang Pedoman Pelaksanaan Reduce, Reuse, Dan Recycle Melalui Bank Sampah," 2013), konsep aktivitas reduce, reuse, dan recycle ini sama dengan membatasi sampah agar sampah ini dapat di daur ulang kembali menjadi sampah yang berguna untuk masyarakat dengan menghasilkan sampah yang layak untuk di gunakan masyarakat dalam mengembangkan kreativitasnya dengan membentuk sebuah produk yang bernilai jual cukup tinggi . Sampah-sampah ini tidak hanya dihimpun akan tetapi di daur ulang hingga mempunyai nilai ekonomis.

Dalam pengolaan sampah terdapat beberapa tahapan yang disebut sebagai 3R (Reduce, Reuse, dan Recycle) Adapun prosesnya menurut Suyoto (2008) dalam (Syahbiba, 2017) sebagai berikut: Reduce, Pada unsur Reduce ini digunakan melalui cara yang dapat dilakukan secara meminimalisir suatu barang atau jenis barang yang digunakan. Reuse, unsur reuse konsep pengolaan dengan cara yang dapat memilih barang yang bisa di gunakan kembali, dengan mengurangi penggunaan barang yang bisa sekali dipakai, maka hal ini akan berdampak panjang dalam memakai barang sebelum barang tersebut menjadi sampah. Recycle, mengunakan konsep pengolaan sampah dengan melakukan 
daur ulang barang-barang yang sudah tidak dipakai. Maka hadirnya Komunitas Bank Sampah Digital sejalan dengan tujuan Peraturan Mentri Lingkungan Hidup Republik Indonesia yaitu Nomor 13 Tahun 2012, yang membantu setiap masyarakat untuk melakukan Kerjasama dalam pengeloalaan sampah, berasaskan gerakan sosial Bank Sampah Digital juga melakukan banyak kegiatan lainnya.

\section{Gerakan Lingkungan Berbasis Digital}

Bank Sampah Digital dapat dikatakan sebagai Gerakan lingkungan berbasis digital karena dalam pelaksanaannya dengan melakukan pemanafaatan berbagai media sosial berkaitan dengan teori menurut (Aditjondro, 2003) Gerakan lingkungan ini merupakan Gerakan Voluntary environmentalist atau Organized Environmentalist, suatu gerakan sosial berbasis lingkungan yang dilakukan oleh komunitas atau kelompok yang terorganisir yang didirikan dengan maksud untuk mengembalikan keseimbangan lingkungan yang dimana pada skala luas bisa menembus lintas negara. Adanya bank sampah itu berasal dari insiatif masyarakat yang berpartisipasi aktif mengenai permasalahan sampah selama ini.

Gerakan yang dilakuan melalui internet atau aktivisme digital merupakan wadah alternatif dalam menyampaikan aspirasi yang minim resiko tetapi mampu memberikan dampak maksimal menurut Laer \& Aelst (2010) dalam (Sanjaya, 2017). Gerakan yang dilakukan melalui beberapa Platform Digital ini benar-benar dimanfaatkan sebagai wadah melakukan Gerakan sosial oleh Bank Sampah Digital. Pemanfaatan media sosial ini ditujukan agar lebih banyak lagi masyarakat yang mengetahui Bank Sampah Digital, selain itu media sosial digunakan untuk menyebaran hal-hal terkait informasi tentang pengelolaan sampah, informasi data sampah terkini, juga sebagai wadah dalam menyampaikan aspirasi terkait Gerakan lingkungan.
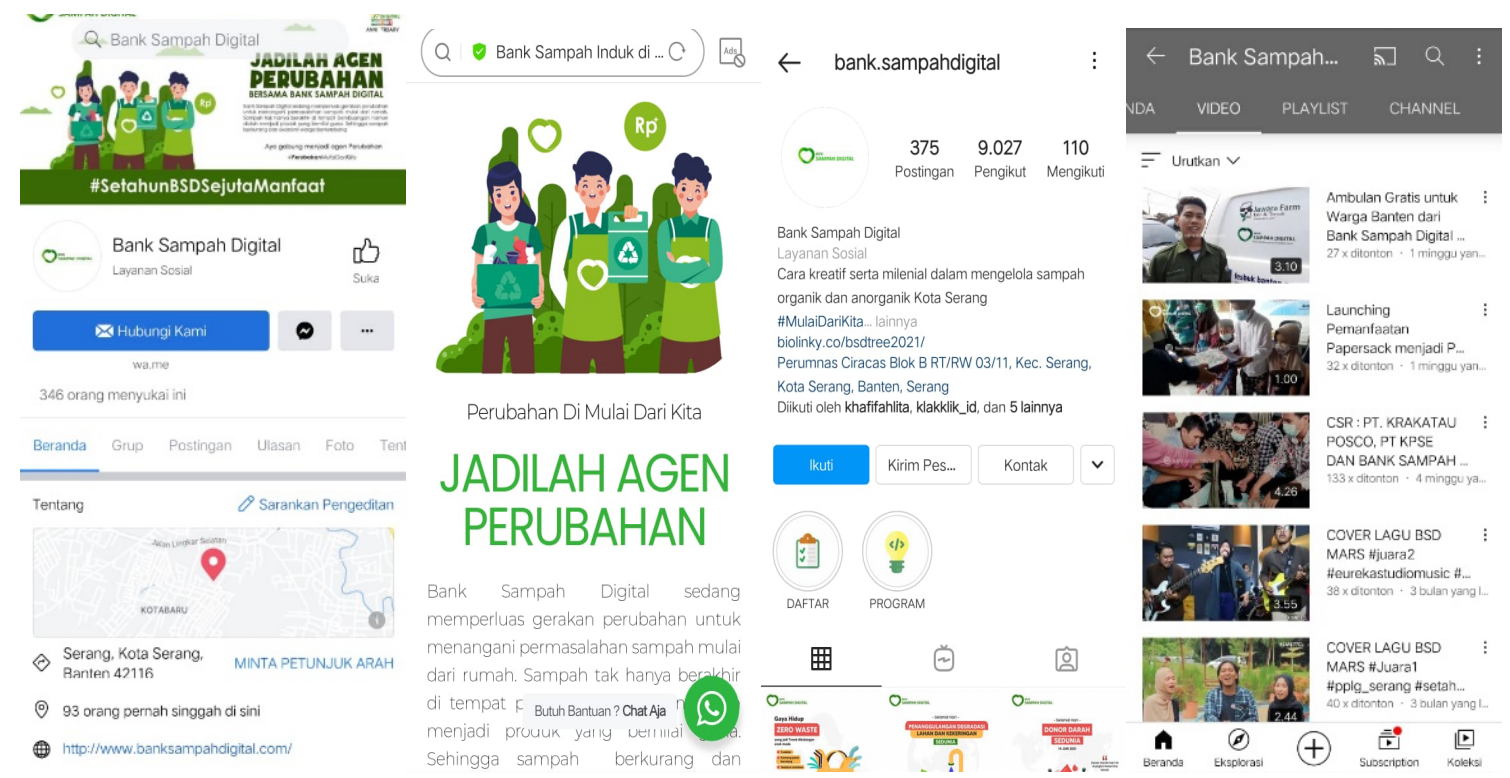

(Sumber : Media Sosia Bank Sampah Digital Kota Serang)

Christenson dan Robinson (1989) dalam (Suraji, 2012) terkait Community Development merupakan suatu proses dalam rangka memprakarsai suatu hal dengan tujuan melaksanakan tindakan atau gerakan untuk mengubah situasi baik situasi sosial, ekonomi, kultural hingga lingkungan yang dilakukan oleh kelompok atau komunitas 
yang sejalan dengan tujuan yang sama tanpa adanya intervensi. Program yang ditawarkan oleh Bank Sampah Digital terdiri dari beberapa program, yaitu:

1. Bank Sampah, yang merupakan program utama dari Bank Sampah Digital kota Serang dengan melakukan pembentukkan titik-titik utama yang akan dijadikan Bank Sampah Digital disetiap RW, yang kemudian dilakukan penimbangan serta pengangkutan sampah terpilah. Dimana program ini terorientasi pada nilai utama hadirnya Bank Sampah Digital yaitu pada Gerakan yang ditujukan untuk lingkungan.

2. Lumbung Pangan yaitu sebuah program ketahanan pangan keluarga dengan berbagi bahan pangan kepada keluarga fakir miskin, renta gizi buruk, rentan stunting serta ODGJ (orang dengan gangguan jiwa). Program yang juga beroirentasi pada nilai sosial.

3. Rumah Edukasi, merupakan training center, pelatihan serta pendampingan pemilihan sampah, pengelolaan sampah serta pelatihan keterampilan untuk masyarakat. Program rumah edukasi ini masuk dalam Community development yang juga memberikan dampak kultural yang ditujukan untuk merubah nilai yang tertanam dalam diri masyarakat terkait sampah dan bagaimana pengolahannya

4. Sedekah Sampah, sedekah sapah yang terpilah disalurkan untuk beasiswa anak yatim, listrik rumah ibadah, dan sembako bagi pemulung serta petugas kebersihan. Sejalan dengan Christenson dan Robinson (1989) dalam (Suraji, 2012) terkait pelaksaan tindakan yang juga beroirentasi pada nilai sosial.

5. BSD Mart adalah wadah wirausaha nasabah dan pengurus bank sampah untuk membangun kemandirian dengan cara berwirausaha. Selain memberi jalan bagi wirausaha atau mitra yang bergabung juga mampu menambah nilai ekonomi bagi mitra, bukan hanya mampu merubah lingkungan tetapi juga mampu menyasar pada pemenuhan perekonomian nasabah.

\section{Kesimpulan}

Bank sampah merupakan suatu kegiatan yang bersifat social enterprise yang bertujuan untuk mengajarkan masyarakat cara mengelola sampah dan membuat kesadaran masyarakat tentang pentingnya mengelola sampah dengan baik dan dapat mengurangi sampah yang ada. Bank sampah digital adalah Lembaga pengelola sampah kering yang berbasis masyarakat dengan platfom digital. Lalu system dari bank sampah adalah mendorong partisipasi aktif dari masyarakat untuk memilah serta menabung sampah bernilai ekonomis.

Sejalan dengan Christenson dan Robinson (1989) dalam (Suraji, 2012) terkait pelaksaan tindakan yang juga beroirentasi pada bidang lain. Bank Sampah Digital yang merupakan suatu komunitas pegiat lingkungan, juga melancarkan kegiatannya dengan diikuti kehadiran program-program Bank Sampah Digital yang dianggap mampu memberikan manfaat pada bidang lain seperti manfaat lingkungan yang dalam hal ini program Bank sampah itu sendiri yang utama, kemudian nilai sosial merujuk pada program Lumbung Pangan, dan Sedekah Sampah, dalam nilai budaya diimplementasikan pada program rumah edukasi untuk merubah nilai yang tertanam dalam diri masyarakat terkait sampah dan bagaimana pengolahannya hingga ekonomi yang diimplemntasikan pada program BSD Mart. 


\section{Tentang Penulis}

Tiara Ayu Rahmadanty merupakan mahasiswa prodi Ilmu Pemerintahan, Fakultas Ilmu Sosial dan Politik Universitas Sultan Ageng Tirtayasa.

Khafifah Nurulita Suheri merupakan mahasiswa prodi Ilmu Pemerintahan, Fakultas Ilmu Sosial dan Politik Universitas Sultan Ageng Tirtayasa.

Nida Nurhopia merupakan mahasiswa prodi Ilmu Pemerintahan, Fakultas Ilmu Sosial dan Politik Universitas Sultan Ageng Tirtayasa.

Lina Mulyanih merupakan mahasiswa prodi Ilmu Pemerintahan, Fakultas Ilmu Sosial dan Politik Universitas Sultan Ageng Tirtayasa.

\section{Ucapan Terima Kasih}

Peneliti mengucapkan terima kasih pada Allah SWT yang telah melancarkan penelitian ini. Kemudian peneliti juga mengucapkan terima kasih kepada M. Dian Hikmawan selaku dosen pengampu mata kuliah Gerakan Sosial dan Masyarakat Sipil yang telah banyak memberikan masukan terkait tulisan ini dan juga kepada Bank Sampah Digital selaku objek penelitian pada tulisan ini.

\section{References}

Aditjondro, G. J. (2003). Pola-pola Gerakan Lingkungan, Refleksi untuk Menyelamatkan Lingkungan dari Ekspansi Modal. PUSTAKA PELAJAR.

Bank sampah digital. Diakses melalui https:/ / www.youtube.com/watch?v=FUBwaircPAg .

Castro, C. J. (2004). Sustainable Development: Mainstream and Critical Perspectives.

Creswell, J. W. (2016). Reaserch Design, pendekaan metode kualitatif, kuantitatif, dan campuran (4th ed.). PUSTAKA PELAJAR.

https:/ / dlh.serangkota.go.id/cilowong

https:/ / www.banksampahdigital.com/

Kairina. F. Hidayati. (2021). Psst, Ada Bank Khusus Pengubah Sampah jadi Lembar Rupiah, Lho!. Diakses melalui https://glints.com/id/lowongan/banksampah/\#.YM6nFmgzbIU.

Peraturan Menteri Negara Lingkungan Hidup Republik Indonesia Nomor 13 Tahun 2012 Tentang Pedoman Pelaksanaan Reduce, Reuse, Dan Recycle Melalui Bank Sampah. (2013). Journal of Chemical Information and Modeling, 53(9), 1689-1699.

Sanjaya, A. R. (2017). Wacana Lingkungan dalam Gerakan Sosial Digital Discourse of Environment in Digital Social Movement. Jurnal IPTEK-KOM (Jurnal Ilmu Pengetahuan Dan Teknologi Komunikasi), 19(2), 133-148.

Suraji. (2012). MENETAS JALAN BARU STUDI PENGEMBANGAN MASYARAKAT ISLAM: Sebuah Jawaban di Era Globalisasi. JURNAL ISLAMIC REVIEW: Jurnal Riset Dan Kajian Keislaman, 1(1), 49-66. http:/ /journal.ipmafa.ac.id/index.php/islamicreview/article/view/6 
Volume 3, Issue 2, August 2021

http://hk-publishing.id/ijd-demos

Syahbiba, I. N. (2017). Studi Kriteria Perencanaan Bank Sampah Melalui Aplikasi Berbasis Android. Doctoral Dissertation, Institut Teknologi Sepuluh Nopember Surabaya.

Wahyuningsih, C. D. (2020). Kenormalan Baru dan Perubahan Sosial Dalam Perspektif Sosiologi. MAjalah Ilmiah FISIP UNTAG Semarang, 1(21), 104-122. 